\title{
Enhanced Capacitative Calcium Entry and Sarcoplasmic- Reticulum Calcium Storage Capacity with Advanced Age in Murine Mesenteric Arterial Smooth Muscle Cells
}

John N. Buchholz

Sean M. Wilson

Ravi Goyal

Gregory D. Smith

William \& Mary, gdsmit@wm.edu

Follow this and additional works at: https://scholarworks.wm.edu/aspubs

Part of the Applied Mathematics Commons

\section{Recommended Citation}

Buchholz, John N.; Wilson, Sean M.; Goyal, Ravi; and Smith, Gregory D., Enhanced Capacitative Calcium Entry and Sarcoplasmic-Reticulum Calcium Storage Capacity with Advanced Age in Murine Mesenteric Arterial Smooth Muscle Cells (2009). Experimental Gerontology, 44(3), 201-207. https://doi.org/10.1016/j.exger.2008.10.007

This Article is brought to you for free and open access by the Arts and Sciences at W\&M ScholarWorks. It has been accepted for inclusion in Arts \& Sciences Articles by an authorized administrator of W\&M ScholarWorks. For more information, please contact scholarworks@wm.edu. 


\title{
Enhanced capacitative calcium entry and sarcoplasmic-reticulum calcium storage capacity with advanced age in murine mesenteric arterial smooth muscle cells
}

\author{
Ravi Goyal ${ }^{\text {a }}$, Jeff E. Angermann ${ }^{\text {c }}$, Olga Ostrovskaya ${ }^{\text {a }}$, John N. Buchholz ${ }^{\mathrm{d}}$, \\ Gregory D. Smith ${ }^{\mathrm{e}}$, Sean M. Wilson a,b,d,* \\ a Department of Pharmacology, University of Mississippi School of Pharmacy and Research Institute of Pharmaceutical Sciences, MS 38677, USA \\ ${ }^{\mathrm{b}}$ University of Mississippi Light Microscopy Core, MS 38677, USA

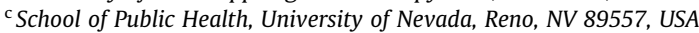 \\ ${ }^{\mathrm{d}}$ Department of Physiology and Pharmacology and Center for Perinatal Biology, Loma Linda University School of Medicine, Loma Linda, CA 92354, USA \\ e Department of Applied Science, College of William and Mary, Williamsburg, VA 23187, USA
}

\section{A R T I C L E I N F O}

\section{Article history:}

Received 21 January 2008

Received in revised form 18 October 2008

Accepted 21 October 2008

Available online 5 November 2008

\section{Keywords:}

fura-2

PMCA

SERCA

SOC

\begin{abstract}
A B S T R A C T
Intracellular $\mathrm{Ca}^{2+}$ signaling is important to perfusion pressure related arterial reactivity and to vascular disorders including hypertension, angina and ischemic stroke. We have recently shown that advancing-age leads to calcium signaling adaptations in mesenteric arterial myocytes from C57 BL/6 mice [Corsso, C.D., Ostrovskaya, O., McAllister, C.E., Murray, K., Hatton, W.J., Gurney, A.M., Spencer, N.J., Wilson, S.M., 2006. Effects of aging on $\mathrm{Ca}(2+)$ signaling in murine mesenteric arterial smooth muscle cells. Mech. Ageing Dev. 127, 315-323)] which may contribute to decrements in perfusion pressure related arterial contractility others have shown occur. Even still, the mechanisms underlying the changes in $\mathrm{Ca}^{2+}$ signaling and arterial reactivity are unresolved. $\mathrm{Ca}^{2+}$ transport and storage capabilities are thought to contribute to age-related $\mathrm{Ca}^{2+}$ signaling dysfunctions in other cell types. The present studies were therefore designed to test the hypothesis that cytosolic and compartmental $\mathrm{Ca}^{2+}$ homeostasis in mesenteric arterial myocytes changes with advanced age. The hypothesis was tested by performing digitalized fluorescence microscopy on mesenteric arterial myocytes isolated from 5- to 6-month and 29- to 30-month-old C57Bl/ 6 mice. The data provide evidence that with advanced age capacitative $\mathrm{Ca}^{2+}$ entry and sarcoplasmic reticulum $\mathrm{Ca}^{2+}$ storage are increased although sarcoplasmic reticulum $\mathrm{Ca}^{2+}$ uptake and plasma membrane $\mathrm{Ca}^{2+}$ extrusion are unaltered. Overall, the studies begin to resolve the mechanisms associated with age-related alterations in mesenteric arterial smooth muscle $\mathrm{Ca}^{2+}$ signaling and their physiological consequences.
\end{abstract}

(c) 2008 Elsevier Inc. All rights reserved.

\section{Introduction}

Intracellular $\mathrm{Ca}^{2+}$ homeostasis of smooth muscle cells is a wellregulated and dynamic process. Myocyte stimulation increases the cytosolic $\mathrm{Ca}^{2+}$ concentration $\left(\left[\mathrm{Ca}^{2+}\right]_{\mathrm{i}}\right)$, which induces actin-myosin crossbridge cycling. Ultimately, this results in contraction and a narrowing of the arterial lumen. These activity-dependent cytosolic $\left[\mathrm{Ca}^{2+}\right]$ elevations are due to activation of $\mathrm{Ca}^{2+}$ permeable ion channels on the plasma membrane as well as sarcoplasmic reticulum (Kuriyama et al., 1998). In particular, L-type $\mathrm{Ca}^{2+}\left(\mathrm{Ca}_{\mathrm{L}}\right)$ as well as $\mathrm{Na}^{+}$and $\mathrm{Ca}^{2+}$ permeable non-selective cation (NSC) channels provide for $\mathrm{Ca}^{2+}$ influx across the plasma membrane, while $\mathrm{InsP}_{3}$ receptors and ryanodine receptors release $\mathrm{Ca}^{2+}$ from the sarcoplasmic reticu-

\footnotetext{
* Corresponding author. Address: Center for Perinatal Biology, Loma Linda University School of Medicine, 11234 Anderson Street, Loma Linda, CA 92354, USA. Tel.: +1 909558 4325; fax: +1 9095584029.

E-mail address: seanwilson@llu.edu (S.M. Wilson).
}

lum (Davis and Hill, 1999; Kuriyama et al., 1998). Following an increase in the cytosolic $\left[\mathrm{Ca}^{2+}\right]_{i}$, the $\mathrm{Ca}^{2+}$ is buffered by proteins such as calmodulin. The $\mathrm{Ca}^{2+}$ ions are then released from the buffers and transported into the sarcoplasmic reticulum by sarcoplasmic-endoplasmic $\mathrm{Ca}^{2+}$ ATPases (SERCA) or out of the cell by plasma membrane $\mathrm{Ca}^{2+}$ ATPases or $\mathrm{Na}^{+} / \mathrm{Ca}^{2+}$ exchangers (Wagner and Keizer, 1994; Keizer et al., 1995; Smith et al., 1996; Brini et al., 2002; Blaustein et al., 2002; Thayer et al., 2002; Gros et al., 2003; Rosker et al., 2004; Zhang et al., 2005).

Given the intimate link between $\mathrm{Ca}^{2+}$ and smooth muscle contractility, it is not surprising that $\mathrm{Ca}^{2+}$ homeostasis alterations likely contribute to vascular diseases such as hypertension, angina and ischemic stroke. This is particularly true as $\mathrm{Ca}_{\mathrm{L}}$ blockers are effective antihypertensive agents. Even still, there are varying changes in smooth muscle excitability with aging in arterioles isolated from different vascular beds. Nor-epinephrine induced vascular reactivity was significantly reduced in skeletal muscle arterioles from 24-month when compared to 4-month-old rats (Muller-Delp 
et al., 2002). This suggests there are age-related decrements in receptor coupling mechanisms. Previous evidence shows reduced agonist mediated as well as $\mathrm{K}^{+}$-induced contractions in aorta from old rats, implying $\mathrm{Ca}_{\mathrm{L}}$ function may also be decreased (Delp et al., 1995). In mesenteric arteries from $\mathrm{C} 57 \mathrm{Bl} / 6$ mice, the ability of the arteries to constrict in response to increases in perfusion pressure diminishes during the first year (Gros et al., 2002). However, the cellular pathways responsible for this altered reactivity with advancing-age are presently unknown. Our recent findings provide some mechanistic details that might contribute to this decrement in arterial reactivity with age. In mesenteric myocytes from elderly mice, there was a depression in ryanodine receptor and $\mathrm{InsP}_{3}$ receptor driven $\mathrm{Ca}^{2+}$ signals but not the functional expression of $\mathrm{Ca}_{\mathrm{L}}$ (Corsso et al., 2006). One shared element between $\operatorname{InsP}_{3}$ and ryanodine receptor dependent $\mathrm{Ca}^{2+}$ signaling is that activation of either receptor releases $\mathrm{Ca}^{2+}$ from the sarcoplasmic reticulum into the cytosol, which is then cleared back into the sarcoplasmic reticulum or transported across the plasma membrane.

The cellular pathways important to sarcoplasmic reticulum $\mathrm{Ca}^{2+}$ signaling and cytosolic $\mathrm{Ca}^{2+}$ homeostasis change with advancingage. In the aging brain, there is reduced $\mathrm{Ca}^{2+}$ buffering (Verkhratsky and Toescu, 1998) as well as SERCA and plasma membrane $\mathrm{Ca}^{2+}$ ATPase function (Michaelis et al., 1996; Pottorf et al., 2000; Vanterpool et al., 2005). Similarly, $\mathrm{Na}^{+} / \mathrm{Ca}^{2+}$ exchanger function is depressed in heart (Janapati et al., 1995). Related to these findings, alterations in plasma membrane extrusion or sarcoplasmic reticulum $\mathrm{Ca}^{2+}$ uptake capabilities greatly affect $\mathrm{Ca}^{2+}$ signaling in numerous cell types including T-lymphocytes (Dolmetsch and Lewis, 1994; Bautista et al., 2002), neurons (Blaustein et al., 2002; Pottorf et al., 2000; Thayer et al., 2002; Vanterpool et al., 2005), astrocytes (Blaustein et al., 2002), smooth muscle cells (Janssen et al., 1997; Zhang et al., 2005), and Chinese hamster ovary cells (Brini et al., 2002). Any alteration in $\mathrm{Ca}^{2+}$ clearance at either the sarcoplasmic reticulum or plasma membrane is therefore likely to affect arterial reactivity. The intimate relationships between sarcoplasmic reticulum $\mathrm{Ca}^{2+}$ release, cytosolic $\mathrm{Ca}^{2+}$ homeostasis, and arterial contractility lead to the proposal that there are reductions in plasma membrane $\mathrm{Ca}^{2+}$ transport as well as sarcoplasmic reticulum $\mathrm{Ca}^{2+}$ sequestration and storage abilities with advanced age. These hypotheses were examined in mesenteric arterial smooth muscle cells (MASMCs) from 5- to 6- (mature) and 29- to 30-month (old) $\mathrm{C} 57 \mathrm{bl} / 6$ mice.

\section{Methods}

\subsection{Cell isolation}

Smooth muscle cells were isolated from murine mesenteric arteries from male C57BL/6 mice purchased from Harlan Sprague-Dawley. These mice were anesthetized and then euthanized with $\mathrm{CO}_{2}$, as approved by the University of Mississippi Institutional Animal Care and Use Committee. The mesentery, including the vasculature and gut was excised en bloc. Arteries $<250 \mu \mathrm{M}$ were dissected at $5{ }^{\circ} \mathrm{C}$ to decrease cellular metabolic activity in a low- $\mathrm{Ca}^{2+}$ physiological saline solution (PSS) containing in $\mathrm{mM}$ : $125 \mathrm{NaCl} ; 5.36 \mathrm{KCl} ; 0.336 \mathrm{Na}_{2} \mathrm{HPO}_{4} ; 0.44 \mathrm{~K}_{2} \mathrm{HPO}_{4} ; 11$ HEPES; 1.2 $\mathrm{MgCl}_{2} ; 0.05 \mathrm{CaCl}_{2} ; 10$ glucose; 2.9 sucrose, $\mathrm{pH} 7.4$ (adjusted with Tris), osmolarity 300 mOsm (adjusted with sucrose). Arteries were cleaned of adipose and connective tissues, cut into small pieces and placed in a tube containing fresh PSS. Tissue was then immediately digested. To disperse cells, tissue was placed in low- $\mathrm{Ca}^{2+}$ PSS containing (in $\mathrm{mg} / \mathrm{ml}$ ): 1.67 collagenase type XI; 0.13 elastase type IV, and 0.67 bovine serum albumin (fat free) for $18-23 \mathrm{~min}$ at $34^{\circ} \mathrm{C}$. The tissue was then washed several times in warm $\left(34^{\circ} \mathrm{C}\right)$ low$\mathrm{Ca}^{2+}$ PSS, and subsequently triturated with fire-polished Pasteur pipettes. The resulting dispersed MASMCs were cold stored at $5{ }^{\circ} \mathrm{C}$ up to $8 \mathrm{~h}$ until experiments were performed.

\subsection{Global $\mathrm{Ca}^{2+}$ measurements}

Cytosolic $\left[\mathrm{Ca}^{2+}\right]$ was measured in SMCs loaded with the ratiometric $\mathrm{Ca}^{2+}$ sensitive dye fura-2 AM (Molecular Probes, Eugene, OR) using a dual excitation digital $\mathrm{Ca}^{2+}$ imaging system (IonOptix Inc., Milton, MA) equipped with an intensified charged coupled device (CCD) camera. The imaging system was mounted on an inverted microscope (Nikon) outfitted with a $40 \times$ (NA 1.3, Nikon Inc., Melville, NY) oil immersion objective. Fura-2 AM was dissolved in DMSO and added from a $1 \mathrm{mM}$ stock to the cell suspension at a final concentration of $10 \mu \mathrm{M}$. Cells were loaded with fura2 AM for 20-25 min in a perfusion chamber (Warner Instruments, Hamden, CT) at room temperature in the dark. Cells were then washed for $30 \mathrm{~min}$ to allow for dye esterification at $1 \mathrm{ml} / \mathrm{min}$ with a balanced salt solution of the following composition (mM): 126 $\mathrm{NaCl} ; 5 \mathrm{KCl} ; 0.3 \mathrm{NaH}_{2} \mathrm{PO}_{4} ; 10$ Hepes; $1 \mathrm{MgCl}_{2} ; 2 \mathrm{CaCl}_{2} ; 10$ glucose; pH 7.4 (adjusted with $\mathrm{NaOH}) 300$ mOsm. In all experiments, cells were continuously perfused with a peristaltic pump (Rainin, Woburn, MA) and solution flow controlled with a multichannel Valvebank computerized system connected to pinch valves (Automate Scientific, Berkeley, CA). Cells were illuminated with a xenon arc lamp at $340 \pm 15$ and $380 \pm 15 \mathrm{~nm}$ (Chroma Technology, Rockingham, VT) and emitted light was collected from regions that encompassed single cells with a CCD at $510 \pm \mathrm{nm}$. In most experiments, images were acquired at $1 \mathrm{~Hz}$ and stored on either compact disk or magnetic media for later analysis. Intracellular calcium $\left(\left[\mathrm{Ca}^{2+}\right]_{\mathrm{i}}\right)$ was estimated from the ratio of fluorescence excited at 340 and $380 \mathrm{~nm}(R)$ as described by Grynkiewicz et al. (1985), assuming a $K_{\mathrm{D}}$ for $\mathrm{Ca}^{2+}$ binding to fura-2 of $224 \mathrm{nM}$ (Grynkiewicz et al., 1985) from the relation,

$\left[\mathrm{Ca}^{2+}\right]_{\mathrm{i}}=K d *\left(\mathrm{Sf}_{2} / \mathrm{Sb}_{2}\right) *\left(R-R_{\min }\right) /\left(R_{\max }-R\right)$

where the values for $F_{380}$ in the absence of extracellular $\mathrm{Ca}^{2+}\left(\mathrm{Sf}_{2}\right)$, $F_{380}$ in the presence of $10 \mathrm{mM}$ extracellular $\mathrm{Ca}^{2+}\left(\mathrm{Sb}_{2}\right)$, minimum ratio $\left(R_{\min }\right)$, and maximum ratio $\left(R_{\max }\right)$ were determined from in situ calibrations of fura- 2 for each cell. These in situ calibrations were carried out at the end of each experiment after applying $1 \mu \mathrm{M}$ ionomycin. To determine the maximum ratio, $R_{\max }$, cells were perfused with a balanced salt solution that contained $10 \mathrm{mM} \mathrm{Ca}^{2+}$, while the minimum ratio, $R_{\min }$, was obtained after applying balanced salt solution that did not have any added $\mathrm{Ca}^{2+}$ and contained $10 \mathrm{mM}$ EGTA. The amplitudes of the increase in cytosolic $\left[\mathrm{Ca}^{2+}\right]$ due to depletion of the sarcoplasmic reticulum $\mathrm{Ca}^{2+}$ stores are expressed relative to baseline values. Background fluorescence was collected automatically and subtracted from the acquired fluorescence video images during each experiment. The $\mathrm{Ca}^{2+}$ free balanced salt solution was prepared by substituting $\mathrm{MgCl}_{2}$ for $\mathrm{CaCl}_{2}$ and adding $1 \mathrm{mM}$ EGTA. All experiments were performed at room temperature 22$25^{\circ} \mathrm{C}$.

\subsection{Chemicals and drugs}

Ionomycin free acid was purchased from Calbiochem (San Diego, CA) and all other chemicals were purchased from Sigma (St. Louis, MO).

\subsection{Statistical analysis}

All curve fitting and integration routines were performed with IGOR pro 3.0 (Wavemetrics, Lake Oswego, OR). All data are presented as means \pm SEM. Statistical difference was determined with either a two-tailed paired or unpaired Student's $t$ test. The specific 
test used for each data set is noted in the legend for each figure. A $P$ value $<0.05$ was accepted as statistically significant. Multiple trials were performed on cells isolated from multiple mice for each experimental paradigm. The specific number of cells and animals evaluated are provided in the legend for each figure. Notably, measurements $\mathrm{Ca}^{2+}$ concentration and rates of $\mathrm{Ca}^{2+}$ movement across the plasma membrane and sarcoplasmic reticulum were performed on myocytes isolated from the same animals.

\subsection{Abbreviations}

$1 / \tau_{\mathrm{SR}}$, the rate constant for the leak of $\mathrm{Ca}^{2+}$ from the sarcoplasmic reticulum; $\mathrm{Ca}_{\mathrm{L}}$, L-type $\mathrm{Ca}^{2+}$ channel; $\mathrm{CPA}$, cyclopiazonic acid; $\mathrm{InsP}_{3}$, inositol-1,4,5-trisphosphate; $J_{i n}, \mathrm{Ca}^{2+}$ influx rate; MASMC, mesenteric arterial smooth muscle cell; $m_{\text {clear }}$, plasma membrane $\mathrm{Ca}^{2+}$ clearance; $\mathrm{NSC}, \mathrm{Na}^{+}$and $\mathrm{Ca}^{2+}$ permeable non-selective cation channels; $Q(t)$, fractional release of $\mathrm{Ca}^{2+}$ from the sarcoplasmic reticulum; SERCA, sarcoplasmic endoplasmic reticulum calcium ATPase; $Z_{o}$, releasable content of the sarcoplasmic reticulum $\left[\mathrm{Ca}^{2+}\right]$ store.

\section{Results}

\subsection{Effect of aging on basal $\mathrm{Ca}^{2+}$ and capacitative $\mathrm{Ca}^{2+}$ entry}

Fig. 1 shows the average basal cytosolic $\left[\mathrm{Ca}^{2+}\right]$ measured in MASMCs from mature and old mice. Cells from mature mice had a basal $\left[\mathrm{Ca}^{2+}\right]$ of $102 \pm 19 \mathrm{nM}$, which was not significantly different than that measured in cells from old mice ( $96 \pm 11 \mathrm{nM})$. It is interesting to note that the basal $\mathrm{Ca}^{2+}$ levels reported here are approximately 2 -fold greater than what we showed previously (Corsso et al., 2006). This is likely a temperature dependent effect as the current experiments were performed at room temperature while the previous study was performed roughly $10^{\circ} \mathrm{C}$ warmer, being approximately $33^{\circ} \mathrm{C}$. The differences in experimental temperature could influence the binding of $\mathrm{Ca}^{2+}$ to fura- 2 and thus affect the reported $\left[\mathrm{Ca}^{2+}\right]$ values. Elevations in temperature can also increase protein activity, which may cause complex changes in the regulation of cytosolic $\left[\mathrm{Ca}^{2+}\right]$ relative to our previous study (Corsso et al., 2006). In addition, these data are consistent with basal $\left[\mathrm{Ca}^{2+}\right]$ levels made at room temperature in peripheral neurons that innervate blood vessels (Vanterpool et al., 2005) and pulmonary arterial myocytes (Ostrovskaya et al., 2007).

Fig. 2 shows that depletion of the sarcoplasmic reticulum $\mathrm{Ca}^{2+}$ stores results in a sustained cytosolic $\mathrm{Ca}^{2+}$ elevation consistent with capacitative calcium entry activation (Goyal et al., 2008; Wilson et al., 2002; Ng et al., 2005, 2007). Fig. 2A shows an exemplary tracing of the $\mathrm{Ca}^{2+}$ signal over time in a MASMC from an older mouse. In this cell, the sarcoplasmic reticulum $\mathrm{Ca}^{2+}$ stores were fully depleted by bathing the cell in $\mathrm{a} \mathrm{Ca}^{2+}$ free solution in the

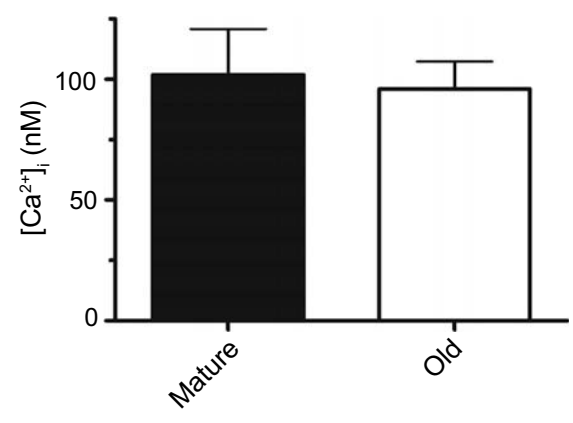

Fig. 1. The basal cytosolic $\mathrm{Ca}^{2+}$ concentration is unchanged in MASMCs with aging. Error bars represent \pm SEM. No significant difference was observed by an unpaired $t$-test $(P=0.78)$. Recordings were performed in 22 cells from 3 mature and 33 cells from 4 old mice.
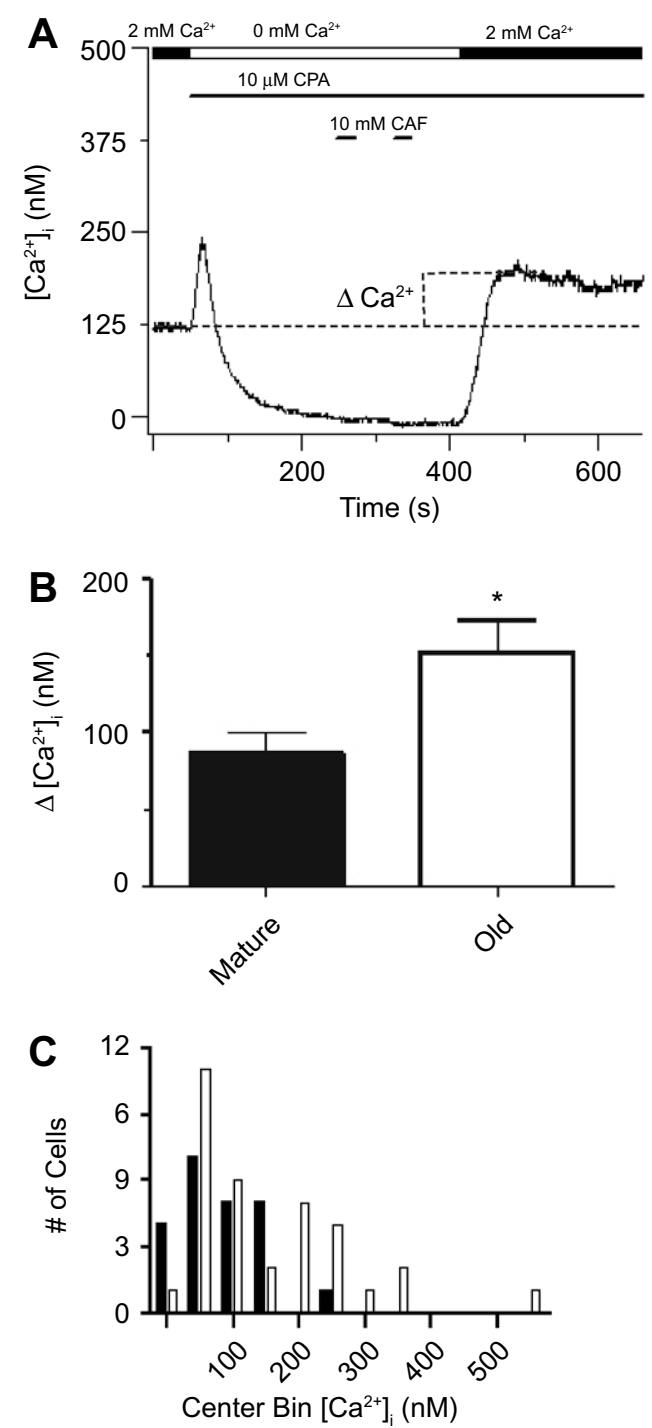

Fig. 2. Capacitative $\mathrm{Ca}^{2+}$ entry is elevated in MASMCs with aging. (A) Cytosolic $\mathrm{Ca}^{2+}$ recording for a myocyte from an old mouse. The recording shows the effect of extracellular $\mathrm{Ca}^{2+}$ removal, $10 \mu \mathrm{M}$ CPA addition, and sequential exposure to $10 \mathrm{mM}$ caffeine and extracellular $\mathrm{Ca}^{2+}$ re-addition on the cytosolic $\left[\mathrm{Ca}^{2+}\right]$. (B) Bars indicate the change in cytosolic $\left[\mathrm{Ca}^{2+}\right]$ from basal levels measured during $\mathrm{Ca}^{2+}$ re-addition for cells from mature (solid) and old (open) mice. Dashed line shows the basal cytosolic $\left[\mathrm{Ca}^{2+}\right]$. (C) Histogram plot of $Z_{o}$ showing the number of myocytes at each center bin shown in panel B for mature (solid bars) and old (open bars) mice. Error bars represent \pm SEM. "Denotes significant difference by an unpaired $t$-test with Welch's correction for unequal variances $(P<0.01)$. Recordings were performed in 22 cells from 3 mature and 33 cells from 4 old mice.

continuous presence of $10 \mu \mathrm{M}$ cyclopiazonic acid (CPA), which inhibits the sarcoplasmic-endoplasmic reticulum $\mathrm{Ca}^{2+}$ ATPase (SERCA), and thereby facilitates depletion of the intracellular $\mathrm{Ca}^{2+}$ stores. This depletion occurs because the sarcoplasmic reticulum is in a state of dynamic equilibrium whereby $\mathrm{Ca}^{2+}$ is continuously pumped into the sarcoplasmic reticulum compartment by SERCA, and continuously released or passively leaked from it. The CPAinduced SERCA inhibition in combination with extracellular $\mathrm{Ca}^{2+}$ removal caused a substantial cytosolic $\mathrm{Ca}^{2+}$ increase, as illustrated by the initial peak in Fig. 2A. This CPA-induced increase in the cytosolic $\left[\mathrm{Ca}^{2+}\right]$ is presumably due to passive leak of $\mathrm{Ca}^{2+}$ from the sarcoplasmic reticulum. However, as the cells are bathed in a zero calcium solution, there is also a unidirectional $\mathrm{Ca}^{2+}$ flux through the cytosol, and across the plasma membrane. Ultimately, this movement of $\mathrm{Ca}^{2+}$ out of the cell depletes 
the intracellular $\mathrm{Ca}^{2+}$ stores and, as shown in Fig. 2A, this reduces the cytosolic $\left[\mathrm{Ca}^{2+}\right]$ to values that are often less than what is observed under basal conditions. This response is similar to that we reported previously in canine pulmonary and renal arterial myocytes (Wilson et. al., 2002), and in fetal and adult ovine pulmonary arterial myocytes (Goyal et al., 2008), and to that reported in T-lymphocytes (Bergling et al., 1998). Depletion of $\mathrm{Ca}^{2+}$ from the sarcoplasmic reticulum was verified by exposing the cells to $10 \mathrm{mM}$ caffeine twice for $30 \mathrm{~s}$, and the lack of a $\mathrm{Ca}^{2+}$ response, as shown in Fig. $2 \mathrm{~A}$, was taken as an indicator that the sarcoplasmic reticulum was devoid of releasable $\mathrm{Ca}^{2+}$. After this, extracellular $\mathrm{Ca}^{2+}$ was added to the bathing solution containing $10 \mu \mathrm{M} \mathrm{CPA}$ and the cytosolic $\left[\mathrm{Ca}^{2+}\right]$ increased $100 \mathrm{nM}$ above basal values. This $\mathrm{Ca}^{2+}$ increase is indicative of capacitative calcium entry (Goyal et al., 2008; Wilson et al., 2002; Ng et al., 2005, 2007). Fig. 2B shows a graphical representation of the change in the mean cytosolic $\left[\mathrm{Ca}^{2+}\right]$ values after depleting the sarcoplasmic reticulum stores, and activating capacitative calcium entry by reintroducing $2 \mathrm{mM} \mathrm{Ca}^{2+}$ with $10 \mu \mathrm{M}$ $\mathrm{CPA}$. The figure provides evidence that there is a 2 -fold increase in the development of capacitative calcium entry with advanced age, where the mean increase in the cytosolic $\left[\mathrm{Ca}^{2+}\right]$ was $86 \pm 13 \mathrm{nM}$ in cells from mature mice and $152 \pm 21 \mathrm{nM}$ for cells isolated from old mice. Fig. $2 \mathrm{C}$ shows a histogram analysis of the mean data shown in Fig. 2B illustrating the heterogeneity of the capacitative calcium entry response for individual cells, and providing further evidence that capacitative calcium entry is augmented in myocytes from older mice.

\subsection{Effect of aging on plasma membrane $\mathrm{Ca}^{2+}$ clearance}

The potential for alterations in cytosolic $\mathrm{Ca}^{2+}$ clearance with advanced age were evaluated using experimental and mathematical approaches developed by Keizer and co-workers (Bergling et al., 1998). The analysis is based on several simple mechanistic assumptions. A primary assumption is that in an un-stimulated myocyte the basal cytosolic $\left[\mathrm{Ca}^{2+}\right]$ is maintained through a dynamic equilibrium of balanced fluxes across the plasma membrane and sarcoplasmic reticulum. As such, the sarcoplasmic reticulum $\left[\mathrm{Ca}^{2+}\right]$ is maintained by equal and opposing influences of $\mathrm{Ca}^{2+}$ uptake by the SERCA pump and continuous passive leak. Cyclopiazonic acid is assumed to instantaneously inhibit $\mathrm{Ca}^{2+}$ uptake into the sarcoplasmic reticulum. The resultant unregulated passive leak from the sarcoplasmic reticulum is assumed to be proportional to the concentration gradient between the sarcoplasmic reticulum and the cytosol; this leak is approximately proportional to the $\left[\mathrm{Ca}^{2+}\right]$ in the sarcoplasmic reticulum because this concentration is far greater than the cytosolic $\left[\mathrm{Ca}^{2+}\right]$. The mathematical approach also presumes the mechanisms of plasma membrane $\mathrm{Ca}^{2+}$ influx and efflux are a linear function of the cytosolic $\left[\mathrm{Ca}^{2+}\right]$. The rates of change in the cytosolic $\left[\mathrm{Ca}^{2+}\right]$ express the underlying fluxes and includes the influence of rapid $\mathrm{Ca}^{2+}$ buffers (Wagner and Keizer, 1994). The releasable $\mathrm{Ca}^{2+}$ content of the sarcoplasmic reticulum is measured in cytosolic equivalents, which is the increase in the cytosolic $\left[\mathrm{Ca}^{2+}\right]$ if the entire sarcoplasmic reticulum $\mathrm{Ca}^{2+}$ store content were instantaneously distributed throughout the cytosol. This method of measuring the sarcoplasmic reticulum $\mathrm{Ca}^{2+}$ content facilitates comparison between cells of different size, which is especially important as cells from old mice are substantially larger than those from mature (Corsso et al., 2006).

Fig. 3A shows a representative recording of cytosolic $\mathrm{Ca}^{2+}$ clearance in a myocyte isolated from an old mouse. The experimental design entails depletion of the sarcoplasmic reticulum $\mathrm{Ca}^{2+}$ stores, activation and measurement of capacitative calcium entry $\left(\left[\mathrm{Ca}^{2+}\right]_{\mathrm{CCE}}\right)$ (i.e. Fig. 2) and lastly removal of extracellular $\mathrm{Ca}^{2+}$.
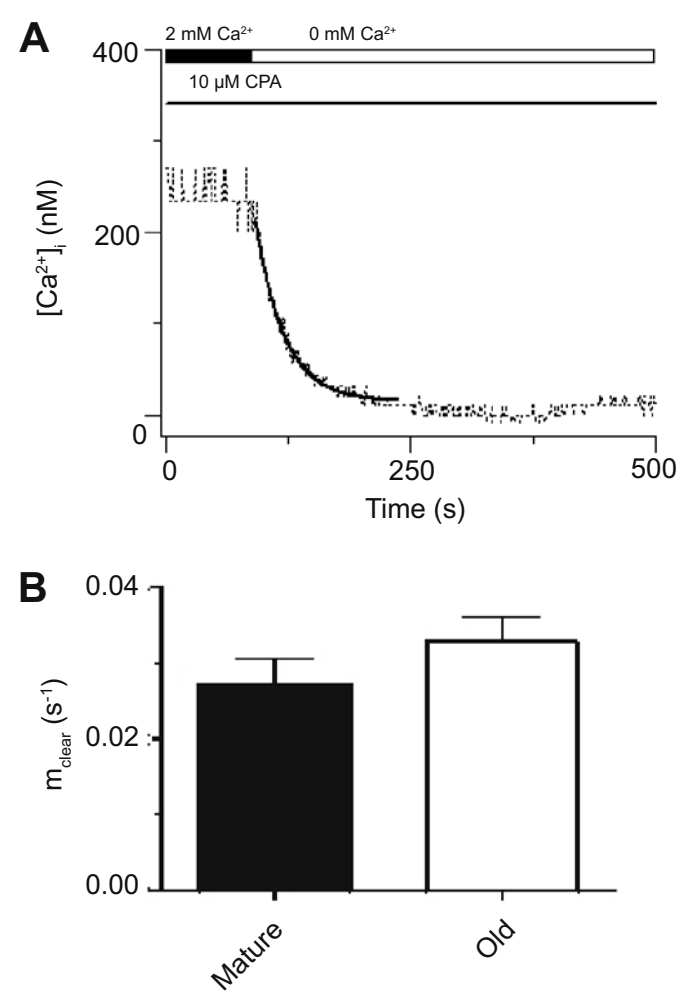

Fig. 3. Plasma membrane $\mathrm{Ca}^{2+}$ transport is unchanged in MASMCs with aging. (A) Cytosolic $\mathrm{Ca}^{2+}$ recording (dashed lines) for a myocyte from an old mouse, and the resultant exponential curve fit to the data (solid lines). Recording shows the effect of extracellular $\mathrm{Ca}^{2+}$ removal in the presence of $10 \mu \mathrm{M}$ CPA once the sarcoplasmic reticulum $\mathrm{Ca}^{2+}$ stores are depleted using the protocol shown in Fig. 1. (B) Bars indicate the plasma membrane clearance rate constant $\left(m_{\text {clear }}\right)$ for cells from mature (solid) and old (open) mice. Error bars represent \pm sem. No significant difference was observed by an unpaired $t$-test $(P=0.26)$. Recordings were performed in 18 cells from 3 mature and 25 cells from 4 old mice.

During this last phase of extracellular $\mathrm{Ca}^{2+}$ removal, the rate constant of plasma membrane $\mathrm{Ca}^{2+}$ clearance $\left(m_{\text {clear }}\right)$ is measured by fitting the data with an exponential function

$$
\left[\mathrm{Ca}^{2+}\right]_{\mathrm{i}}(t)=\left[\mathrm{Ca}^{2+}\right]_{\mathrm{i}}\left(t_{\infty}\right)+\left[\mathrm{Ca}^{2+}\right]_{\mathrm{i}}(0) \exp \left(-m_{\text {clear }} t\right)
$$

The experimental protocol is similar to ones used previously to examine capacitative calcium entry in pulmonary and renal arterial smooth muscle cells (Wilson et al., 2002; Goyal et al., 2008), T-lymphocytes (Bergling et al., 1998), HEK-293 cells (Shalabi et al., 2004), and A7R5 cells (Soboloff et al., 2005). The $\mathrm{Ca}^{2+}$ decay curves used to compute $m_{\text {clear }}$ (Fig. 3A) was well fit by equation 2 and similar to those published for T-lymphocytes (Bergling et al., 1998), with $m_{\text {clear }}$ being $0.034 \mathrm{~s}^{-1}$ for the myocyte shown in Fig. 3A. As shown in Fig. 3B, there were no significant differences in the average $m_{\text {clear }}$ measurements for mature and old myocytes, being $0.027 \pm 0.004 \mathrm{~s}^{-1}$ in cells isolated from mature mice and $0.033 \pm 0.003 \mathrm{~s}^{-1}$ in cells from old mice.

\subsection{Effect of aging on sarcoplasmic reticulum $\mathrm{Ca}^{2+}$ uptake and storage}

Given the simple mechanistic assumptions described above, when sarcoplasmic reticulum $\mathrm{Ca}^{2+}$ uptake is inhibited and extracellular $\mathrm{Ca}^{2+}$ influx abolished the releasable $\mathrm{Ca}^{2+}$ content from the sarcoplasmic reticulum can be measured in cytosolic equivalents as given by (Bergling et al., 1998)

$z_{0}=\int_{0}^{t_{\infty}} m_{\text {clear }} \Delta\left[\mathrm{Ca}^{2+}\right]\left(t^{\prime}\right) d t^{\prime}$ 

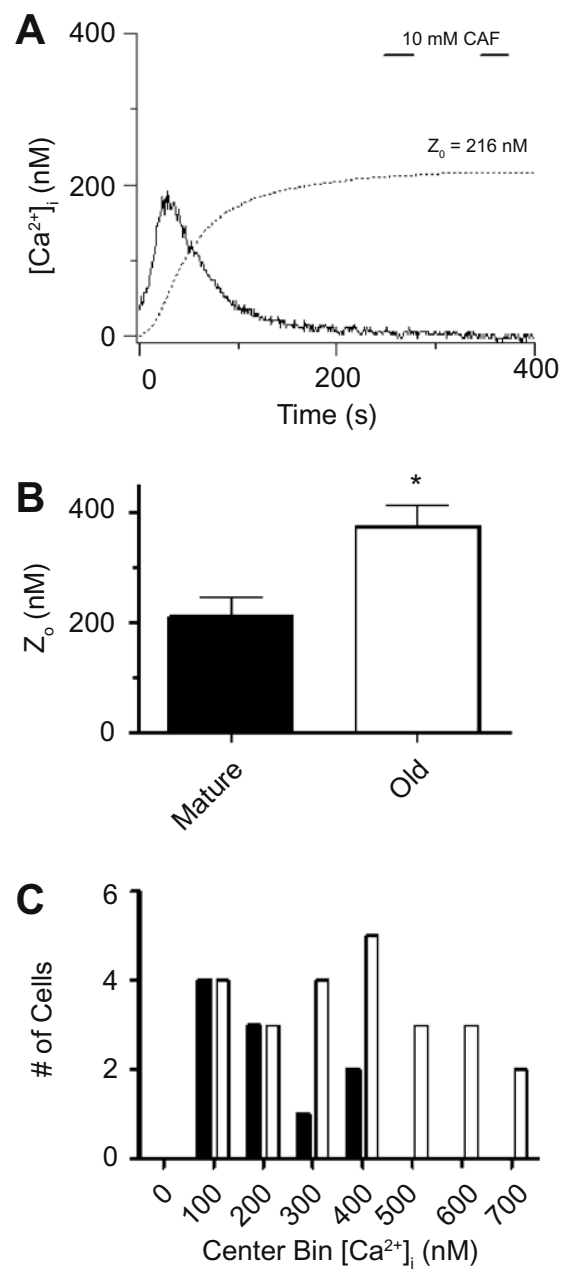

Fig. 4. Sarcoplasmic reticulum $\mathrm{Ca}^{2+}$ storage is increased in MASMCs with aging. (A) Cytosolic $\mathrm{Ca}^{2+}$ recording (solid lines) and integrated $\mathrm{Ca}^{2+}$ response (dashed line) for a myocyte from an old mouse in response to extracellular $\mathrm{Ca}^{2+}$ removal and $10 \mu \mathrm{M}$ CPA addition. (B) Bars indicate the integrated $\mathrm{Ca}^{2+}\left(Z_{o}\right)$, which is equivalent to the $\mathrm{Ca}^{2+}$ content in the sarcoplasmic reticulum for cells from mature (solid) and old (open) mice. (C) Histogram plot of $Z_{o}$ showing the number of cells at each center bin shown in panel $C$ for mature (solid bars) and old (open bars). Error bars represent \pm sem. "Denotes significant difference by an unpaired $t$-test $(P<0.02)$. Recordings were performed in 10 cells from 3 mature and 24 cells from 4 old mice.

Based on this equation, in cells where $m_{\text {clear }}$ was measured the releasable content of the sarcoplasmic reticulum $\left[\mathrm{Ca}^{2+}\right]$ store $\left(Z_{o}\right)$ can be estimated. Fig. 4 shows exemplary traces for the $Z_{o}$ computation, which was achieved by integrating the $\mathrm{Ca}^{2+}$ release curve (Eq. 3) at the time points illustrated in Fig. 4A, where extracellular $\mathrm{Ca}^{2+}$ was removed and SERCA was inhibited with $10 \mu \mathrm{M} \mathrm{CPA}$. This method provides the releasable calcium inside the lumen of the sarcoplasmic reticulum, which is responsible for vascular reactivity when the myocyte is activated. The measurement was made as a function of the cytosolic volume, which therefore eliminates the fact that cell morphology is altered with age, and indeed gives an estimate of sarcoplasmic reticulum $\mathrm{Ca}^{2+}$ release in mature and older myocytes. Fig. 4A shows an exemplary trace from an old cell where the $Z_{o}$ was $216 \mathrm{nM}$. Fig. $4 \mathrm{~B}$ shows the average $Z_{o}$ measurements, which were $210 \pm 36 \mathrm{nM}$ in mature cells and greater, $374 \pm 38 \mathrm{nM}$, in old cells. Fig. 4C shows a histogram analysis of the mean data shown in Fig. 4B illustrating the heterogeneity of the storage capacity of individual cells, and providing further evidence that cells from mature mice have smaller sarcoplasmic reticulum $\mathrm{Ca}^{2+}$ stores.
The rate constant for the leak of $\mathrm{Ca}^{2+}$ from the sarcoplasmic reticulum $\left(1 / \tau_{\mathrm{SR}}\right)$ can be computed using the following two relationships (Bergling et al., 1998)

$$
\begin{aligned}
& \ln (Q(t))=-t / \tau_{\mathrm{SR}} \\
& \quad \text { with } \\
& Q(t)=1-\left\{m_{\text {clear }} \int_{0}^{t} \Delta\left[\mathrm{Ca}^{2+}\right]\left(t^{\prime}\right) d t \prime+\Delta\left[\mathrm{Ca}^{2+}\right](t)\right\} / z_{0}
\end{aligned}
$$

Under basal conditions, the rate of sarcoplasmic reticulum $\mathrm{Ca}^{2+}$ release is balanced by sarcoplasmic reticulum $\mathrm{Ca}^{2+}$ uptake and thus $1 / \tau_{\text {SR }}$ provides a measure of SERCA activity.

Further to this, SERCA function can be evaluated by the exponential curve fitting analysis of $Q(t)$ (Eq. 5), which is the fractional release of $\mathrm{Ca}^{2+}$ from the sarcoplasmic reticulum. Fig. 5 shows representative and average data, based on the analysis of $\ln Q(t)$ (Eq. 4). Fig. 5A shows a semi-logarithmic plots of $Q(t)$ for an individual myocyte from an old mouse in a $\mathrm{Ca}^{2+}$-free bathing solution containing $10 \mu \mathrm{M} \mathrm{CPA}$. This data was derived from the CPA-mediated $\mathrm{Ca}^{2+}$ release data shown in Fig. 2A, when extracellular $\mathrm{Ca}^{2+}$ was removed. The decline in fractional $\mathrm{Ca}^{2+}$ release over time was monoexponential in this cell for approximately $90 \%$ of the $\mathrm{Ca}^{2+}$ released from the store, as illustrated by the single exponential curve fit to In $Q(t)$. The decay of cytosolic $\mathrm{Ca}^{2+}$ deviated from the curve fit as the cytosolic $\left[\mathrm{Ca}^{2+}\right]$ became very low. These non-exponential changes in $\ln Q(t)$ were expected as they were also observed in T-lymphocytes (Bergling et al., 1998), and in ovine pulmonary arterial myocytes (Goyal et al., 2008). Fig. 5B shows average data based on this exponential curve fitting analysis with $1 / \tau_{\mathbf{S R}}$ being $0.021 \pm 0.002$ in myocytes from mature and $0.018 \pm 0.002$ in myo-
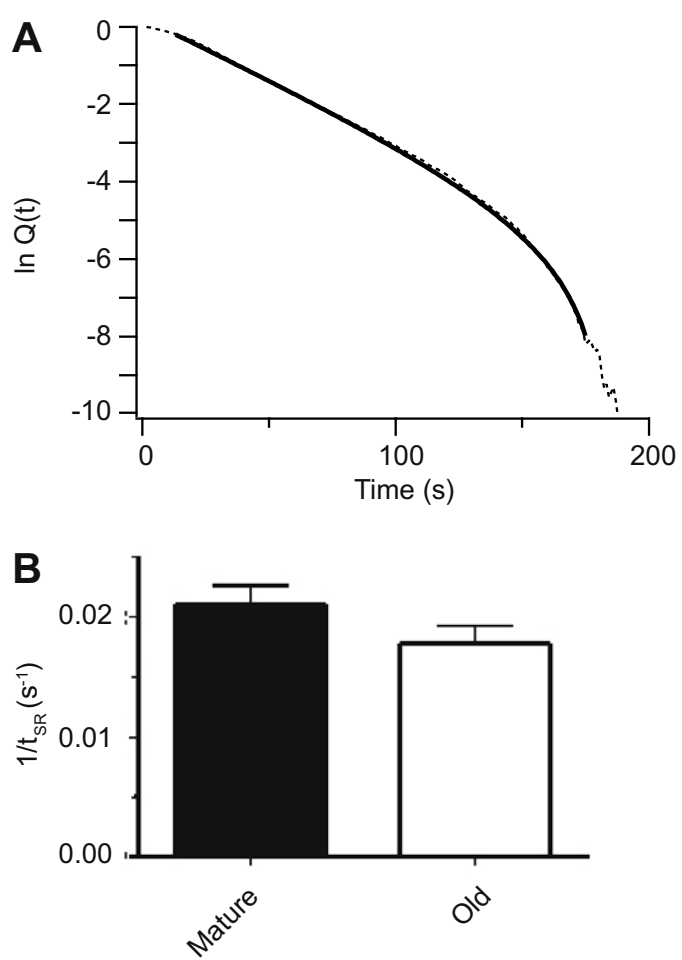

Fig. 5. The rate constant for $\mathrm{Ca}^{2+}$ leak from the sarcoplasmic reticulum is unchanged in MASMCs with aging. (A) Representative semi-logarithmic plot of $Q(t)$ for a myocyte from an old mouse. (B) Bars indicate the clearance rate constant for passive $\mathrm{Ca}^{2+}$ leak from the sarcoplasmic reticulum $\left(1 / \tau_{\mathrm{SR}}\right)$ for cells from mature (solid bars) and old (open bars) mice. Error bars represent \pm sem. No significant differences were found by an unpaired $t$-test $(P=0.21)$. Recordings were performed in 10 cells from 3 mature and 23 cells from 4 old mice. 
cytes from old mice. Based on this analysis, SERCA function was not altered with advanced age.

\section{Discussion}

This is the first report to examine $\mathrm{Ca}^{2+}$ homeostasis in aged smooth muscle using experimental and mathematical analysis techniques of Keizer and co-workers (Bergling et al., 1998), and builds from our report using these techniques in pulmonary arterial myocytes (Goyal et al., 2008). These analytical techniques provide estimates for plasma membrane $\mathrm{Ca}^{2+}$ entry and clearance, SERCA function, and sarcoplasmic reticulum $\mathrm{Ca}^{2+}$ content. The results show increased capacitative calcium entry and sarcoplasmic reticulum storage capacity in mesenteric arterial myocytes from old mice, and maintained plasma membrane $\mathrm{Ca}^{2+}$ clearance as well as SERCA function. This work expands on our recently published report showing hypertrophy and reduced sarcoplasmic reticulum $\mathrm{Ca}^{2+}$ release of mesenteric arterial smooth muscle cells from aged C57Bl/6 mice when compared to cells isolated from mature mice (Corsso et al., 2006).

The increased sarcoplasmic reticulum $\mathrm{Ca}^{2+}$ storage with advanced age was unexpected given that sarcoplasmic reticulum-related $\mathrm{Ca}^{2+}$ signaling is depressed (Corsso et al., 2006). In essence, mesenteric arterial myocytes from aged mice store a greater amount of $\mathrm{Ca}^{2+}$ in their sarcoplasmic reticulum, although it is not released as well. Because our measurement of $\mathrm{Ca}^{2+}$ content is independent of the cell volume, the data suggest the enhanced sarcoplasmic reticulum $\mathrm{Ca}^{2+}$ content may be independent of age-related cellular hypertrophy. This indicates the augmented $\mathrm{Ca}^{2+}$ content may be due to an increase in the proportion of the sarcoplasmic reticulum relative to the total cell volume, or to an increase in the concentration of $\mathrm{Ca}^{2+}$ stored in the sarcoplasmic reticulum.

In general, the sarcoplasmic reticulum $\mathrm{Ca}^{2+}$ content relies on the balance of SERCA dependent $\mathrm{Ca}^{2+}$ uptake to sarcoplasmic reticulum $\mathrm{Ca}^{2+}$ leak (Keizer and De Young, 1993; Bergling et al., 1998). Yet, our computations indicate these parameters remain unchanged with advanced age and thus cannot account for the augmented sarcoplasmic reticulum $\mathrm{Ca}^{2+}$ storage capacity. This compares with aged neurons, where SERCA function and releasable sarcoplasmic reticulum $\mathrm{Ca}^{2+}$ content are reduced (Tsai et al., 1998; Pottorf et al., 2000; Vanterpool et al., 2005).

The enhancement in capacitative calcium entry with advanced age was striking and may provide for the increased sarcoplasmic reticulum $\mathrm{Ca}^{2+}$ storage capacity. Capacitative $\mathrm{Ca}^{2+}$ entry is a ubiquitous process in many cell types such as smooth muscle, lymphocytes, neurons, fibroblasts, and endothelial cells and is activated by release or depletion of the sarcoplasmic-endoplasmic reticulum $\mathrm{Ca}^{2+}$ stores (Putney, 2005). Capacitative $\mathrm{Ca}^{2+}$ entry then acts to refill the intracellular $\mathrm{Ca}^{2+}$ stores (Beech 2005; Putney, 2007). Presumably, increasing the activity of capacitative calcium entry could provide a pathway allowing for augmented sarcoplasmic reticulum $\mathrm{Ca}^{2+}$ content. This would likely be due to an increased function or expression of the ion channels that provide for this $\mathrm{Ca}^{2+}$ influx pathway. The potential for a role of capacitative calcium entry in the filling of the sarcoplasmic reticulum is supported by reports of a superficial buffer barrier in smooth muscle, which provides vectoral $\mathrm{Ca}^{2+}$ transport across the plasma membrane and to the sarcoplasmic reticulum (van Breemen et al., 1995; Yoshikawa et al., 1996; Lee et al., 2002; Poburko et al., 2004). Poisoning SERCA with cyclopiazonic acid would then activate as well as unmask this vectoral-transport pathway, and may explain why SERCA function was unchanged even though releasable store content increased.

The present series of experiments build on our previous studies that show advanced age leads to reduced sarcoplasmic reticulum mediated $\mathrm{Ca}^{2+}$ release events and myocyte hypertrophy (Corsso et al., 2006). The increases in capacitative calcium entry and sarcoplasmic reticulum $\mathrm{Ca}^{2+}$ storage capacity we observed with advanced age may compensate or contribute to the loss in pressure-induced arterial reactivity depicted by Gros et al. (2002). Although unresolved, the molecular determinants underlying the responses illustrated by us and others and their physiological consequences are requisite to understanding mechanistic details important to vascular aging. Comprehension of these age-related transformations in intracellular $\mathrm{Ca}^{2+}$ homeostasis and their importance to arterial function is expected to provide novel therapeutic avenues for the treatment of vascular disease.

\section{Acknowledgments}

Present addresses: Sean Wilson and Ravi Goyal, Center for Perinatal Biology, Loma Linda University School of Medicine, Loma Linda, CA 92354. Olga Ostrovskaya, Pharmacology and Pharmaceutical Sciences, University of Southern California, Los Angeles, CA 90033. We would like to thank Matthew Loftin and Will Graugnard for technical assistance. This work was supported by the National Science Foundation Grant No. MRI 0619774, NIH grant AI55462 and UM faculty fellowship to SMW as well as UM graduate student fellowship and Sigma Xi research fellowship to RG.

\section{References}

Bautista, D.M., Hoth, M., Lewis, R.S., 2002. Enhancement of calcium signalling dynamics and stability by delayed modulation of the plasma-membrane calcium-ATPase in human T cells. J. Physiol. 541, 877-894.

Beech, D.J., 2005. Emerging functions of 10 types of TRP cationic channel in vascular smooth muscle. Clin. Exp. Pharmacol. Physiol. 32, 597-603.

Bergling, S., Dolmetsch, R., Lewis, R.S., Keizer, J., 1998. A fluorometric method for estimating the calcium content of internal stores. Cell Calcium 23, 251-259.

Blaustein, M.P., Juhaszova, M., Golovina, V.A., Church, P.J., Stanley, E.F., 2002. Na/Ca exchanger and PMCA localization in neurons and astrocytes: functional implications. Ann. NY Acad. Sci. 976, 356-366.

Brini, M., Manni, S., Carafoli, E., 2002. Recombinant expression of the plasma membrane $\mathrm{Na}(+) / \mathrm{Ca}(2+)$ exchanger affects local and global $\mathrm{Ca}(2+)$ homeostasis in Chinese hamster ovary cells. J. Biol. Chem. 277, 38693-38699.

Corsso, C.D., Ostrovskaya, O., McAllister, C.E., Murray, K., Hatton, W.J., Gurney, A.M. Spencer, N.J., Wilson, S.M., 2006. Effects of aging on $\mathrm{Ca}(2+)$ signaling in murine mesenteric arterial smooth muscle cells. Mech. Ageing Dev. 127, 315-323.

Davis, M.J., Hill, M.A., 1999. Signaling mechanisms underlying the vascular myogenic response. Physiol, Rev. 79, 387-423.

Delp, M.D., Brown, M., Laughlin, M.H., Hasser, E.M., 1995. Rat aortic vasoreactivity is altered by old age and hindlimb unloading. J. Appl. Physiol. 78, 2079-2086.

Dolmetsch, R.E., Lewis, R.S., 1994. Signaling between intracellular $\mathrm{Ca}^{2+}$ stores and depletion-activated $\mathrm{Ca}^{2+}$ channels generates $\left[\mathrm{Ca}^{2+}\right] \mathrm{i}$ oscillations in $\mathrm{T}$ lymphocytes. J. Gen. Physiol. 103, 365-388.

Goyal, R., Creel, K.D., Chavis, E.J., Smith, G.D., Longo, L.D., Wilson, S.M., 2008 Maturation of intracellular calcium homeostasis in sheep pulmonary arterial smooth muscle cells. Am J Physiol Lung Cell Mol Physiol. 295, L905-L914.

Gros, R., Van Wert, R., You, X., Thorin, E., Husain, M., 2002. Effects of age, gender, and blood pressure on myogenic responses of mesenteric arteries from c57bl/6 mice. Am. J. Physiol. Heart. Cire. Physiol. 282, H380-H388.

Gros, R., Afroze, T., You, X.M., Kabir, G., Van Wert, R., Kalair, W., Hoque, A.E., Mungrue, I.N., Husain, M., 2003. Plasma membrane calcium ATPase overexpression in arterial smooth muscle increases vasomotor responsiveness and blood pressure. Circ. Res. 93, 614-621.

Grynkiewicz, G., Poenie, M., Tsien, R.Y., 1985. A new generation of $\mathrm{Ca}^{2+}$ indicators with greatly improved fluorescence properties. J. Biol. Chem. 260, 3440-3450.

Janapati, V., Wu, A., Davis, N., Derrico, C.A., Levengood, J., Schummers, J., Colvin, R.A., 1995. Post-transcriptional regulation of the $\mathrm{Na}^{+} / \mathrm{Ca}^{2+}$ exchanger in aging rat heart. Mech. Ageing Dev. 84, 195-208.

Janssen, L.J., Walters, D.K., Wattie, J., 1997. Regulation of $\left[\mathrm{Ca}^{2+}\right] \mathrm{i}$ in canine airway smooth muscle by $\mathrm{Ca}\left({ }^{2+}\right)$-ATPase and $\mathrm{Na}^{+} / \mathrm{Ca}^{2+}$ exchange mechanisms. Am. J. Physiol. 273, L322-L330.

Keizer, J., De Young, G., 1993. Effect of voltage-gated plasma membrane $\mathrm{Ca}^{2+}$ fluxes on IP3-linked $\mathrm{Ca}^{2+}$ oscillations. Cell Calcium 14, 397-410.

Keizer, J., Li, Y.X., Stojilkovic, S., Rinzel, J., 1995. InsP3-induced $\mathrm{Ca}^{2+}$ excitability of the endoplasmic reticulum. Mol. Biol. Cell 6, 945-951.

Kuriyama, H., Kitamura, K., Itoh, T., Inoue, R., 1998. Physiological features of visceral smooth muscle cells, with special reference to receptors and ion channels. Physiol. Rev. 78, 811-920.

Lee, C.H., Poburko, D., Kuo, K.H., Seow, C., van Breemen, C., 2002. Relationship between the sarcoplasmic reticulum and the plasma membrane. Novartis. Found. Symp. 246, 26-41. 
Michaelis, M.L., Bigelow, D.J., Schoneich, C., Williams, T.D., Ramonda, L., Yin, D. Huhmer, A.F., Yao, Y., Gao, J., Squier, T.C., 1996. Decreased plasma membrane calcium transport activity in aging brain. Life Sci. 59, 405-412.

Muller-Delp, J., Spier, S.A., Ramsey, M.W., Lesniewski, L.A., Papadopoulos, A., Humphrey, J.D., Delp, M.D., 2002. Effects of aging on vasoconstrictor and mechanical properties of rat skeletal muscle arterioles. Am. J. Physiol. Heart Circ. Physiol. 282, H1843-H1854.

Ng, L.C., Wilson, S.M., Hume, J.R., 2005. Mobilization of sarcoplasmic reticulum stores by hypoxia leads to consequent activation of capacitative $\mathrm{Ca}^{2+}$ entry in isolated canine pulmonary arterial smooth muscle cells. J. Physiol. 563, 409419.

Ng, L.C., Wilson, S.M., McAllister, C.E., Hume, J.R., 2007. Role of insp(3) and ryanodine receptors in the activation of capacitative $\mathrm{ca}(2+)$ entry by store depletion or hypoxia in canine pulmonary arterial smooth muscle cells. Br. J. Pharmacol. 152, 101-111.

Ostrovskaya, O., Goyal, R., Osman, N., McAllister, C.E., Pessah, I.N., Hume, J.R., Wilson, S.M., 2007. Inhibition of ryanodine receptors by 4-(2-Aminopropyl)3,5 -dichloro- $N, N$-dimethylaniline (FLA 365) in canine pulmonary arteria smooth muscle cells. JPET 323, 381-390.

Poburko, D., Lhote, P., Szado, T., Behra, T., Rahimian, R., McManus, B., van Breemen, C., Ruegg, U.T., 2004. Basal calcium entry in vascular smooth muscle. Eur. J. Pharmacol. 505, 19-29.

Pottorf, W.J., Duckles, S.P., Buchholz, J.N., 2000. SERCA function declines with age in adrenergic nerves from the superior cervical ganglion. J. Auton. Pharmacol. 20, 281-290.

Putney, J.W., 2005. Capacitative calcium entry: sensing the calcium stores. J. Cell Biol. 169, 381-382.

Putney Jr., J.W., 2007. New molecular players in capacitative $\mathrm{Ca}^{2+}$ entry. J. Cell Sci. $120,1959-1965$.

Rosker, C., Graziani, A., Lukas, M., Eder, P., Zhu, M.X., Romanin, C., Groschner, K., 2004. $\mathrm{Ca}(2+)$ signaling by TRPC 3 involves $\mathrm{Na}(+)$ entry and local coupling to the $\mathrm{Na}(+) / \mathrm{Ca}(2+)$ exchanger. J. Biol. Chem. 279, 13696-13704
Shalabi, A., Zamudio, F., Wu, X., Scaloni, A., Possani, L.D., Villereal, M.L., 2004. Tetrapandins, a new class of scorpion toxins that specifically inhibit storeoperated calcium entry in human embryonic kidney-293 cells. J. Biol. Chem. 279, 1040-1049.

Smith, G.D. Wagner, J. Keizer, J, 1996. Validity of the rapid buffering approximation near a point source of calcium ions. Biophys. J. 70, 2527-2539.

Soboloff, J., Spassova, M., Xu, W., He, L.P., Cuesta, N., Gill, D.L., 2005. Role of endogenous TRPC6 channels in $\mathrm{Ca}^{2+}$ signal generation in A7r5 smooth muscle cells. J. Biol. Chem. 280, 39786-39794.

Thayer, S.A., Usachev, Y.M., Pottorf, W.J., 2002. Modulating $\mathrm{Ca}^{2+}$ clearance from neurons. Front. Biosci. 7, d1255-d1279.

Tsai, H., Pottorf, W.J., Buchholz, J.N., Duckles, S.P., 1998. Adrenergic nerve smooth endoplasmic reticulum calcium buffering declines with age. Neurobiol. Aging $19,89-96$

van Breemen, C., Chen, Q., Laher, I., 1995. Superficial buffer barrier function of smooth muscle sarcoplasmic reticulum. Trends Pharmacol. Sci. 16, 98-105.

Vanterpool, C.K., Pearce, W.J., Buchholz, J.N., 2005. Advancing age alters rapid and spontaneous refilling of caffeine-sensitive calcium stores in sympathetic superior cervical ganglion cells. J. Appl. Physiol. 99, 963-971.

Verkhratsky, A., Toescu, E.C., 1998. Calcium and neuronal ageing. Trends Neurosci. 21, 2-7.

Wagner, J., Keizer, J., 1994. Effects of rapid buffers on $\mathrm{Ca}^{2+}$ diffusion and $\mathrm{Ca}^{2+}$ oscillations. Biophys. J. 67, 447-456.

Wilson, S.M., Mason, H.S., Smith, G.D., Nicholson, N., Johnston, L., Janiak, R., Hume, J.R., 2002. Comparative capacitative calcium entry mechanisms in canine pulmonary and renal arterial smooth muscle cells. J. Physiol. 543, 917-931.

Yoshikawa, A., van Breemen, C., Isenberg, G., 1996. Buffering of plasmalemmal $\mathrm{Ca}^{2+}$ current by sarcoplasmic reticulum of guinea pig urinary bladder myocytes. Am. J. Physiol. 271, C833-C841.

Zhang, S., Yuan, J.X., Barrett, K.E., Dong, H., 2005. Role of $\mathrm{Na}^{+} / \mathrm{Ca}^{2+}$ exchange in regulating cytosolic $\mathrm{Ca}^{2+}$ in cultured human pulmonary artery smooth muscle cells. Am. J. Physiol. Cell Physiol. 288, C245-C252. 